\title{
A narrative analysis of conversations with graduates who did not pursue teaching: Inputs to teacher education policies in the Philippines
}

\author{
Abulon, Edna Luz Raymundo \\ Education Policy and Research Development Center, Philippine Normal University (abulon.elv@pnu.edu.ph) \\ Rungduin, Teresita T. $\bowtie$ \\ Research Center for Teacher Quality, Philippine Normal University, Philippines (rungduin.tt@pnu.edu.ph)
}

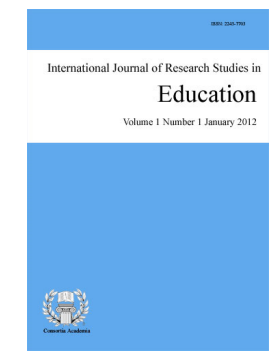

ISSN: 2243-7703 Online ISSN: 2243-7711

OPEN ACCESS

Received: 30 October 2014

Revised: 12 November 2014

Accepted: 11 December 2014

Available Online: 14 December 2014

DOI: $10.5861 /$ ijrse.2014.966

\section{Abstract}

Conversations with 74 Filipino pre-service teachers from 10 Teacher Education Institutions in the Philippines were qualitatively analyzed to explore their experiences in college, their motivations as well as life events, which hindered them from pursuing the teaching as a career. The rich narrative data gathered in the study showed that financial and economic reasons, which include perceptions of insufficient salary levels, are driving the graduates away from teaching. Likewise, a mismatch between personal characteristics, including health issues related to the demands of the teaching profession, was crystallized. Although a number of the respondents admitted that they do not see themselves as teachers even if they were trained as such, yet, they expressed seeing themselves as part of the allied professions in teaching. The graduates reported that they applied for jobs related to teaching such as those involved in child-care, guidance counselors, librarians, teacher assistants, and other teaching-related professions. A myriad of possible reforms and initiatives were considered in the study to address these concerns. In the pre-service phase, reforms starting with the recruitment and selection of students, provision of scholarships for deserving students, institutionalization of career-oriented programs to sustain motivation to pursue teaching, and curricular reviews of the aspects of the practice teaching course, as well as the basic teacher competencies, are recommended. In the in-service phase, reforms in the hiring process, provision of in-service enticements for beginning teachers, and most of all, review of the starting salary of teachers are deemed necessary and timely.

Keywords: motivation; teacher loss; admission and retention policies; narrative analysis 


\section{A narrative analysis of conversations with graduates who did not pursue teaching: Inputs to teacher education policies in the Philippines}

\section{Introduction}

University graduates walk through a transition from the completions of one's degree to the actual entrance into the professional world. However, somewhere along the way some graduates shift careers for various reasons. In the case of graduates of teacher education, a glimpse of some foreign studies on the phenomenon of teacher mobility and loss, teacher labor market and career path analysis of graduates, would point to the increasing incidence of career shifts. Filipino teachers are not spared from such phenomenon and it is quite obvious how Filipino teachers would work in other countries and be underemployed.

Based on observations also, a considerable number of freshman students who enter teacher education programs leave the university even before finishing their degree. Others do not go into teaching after college, opting for jobs not related to teaching. Worst is many who are already in the teaching profession leave their jobs for various reasons. These observations and eventualities have implications to the Philippines' ongoing implementation of the K-12 Basic Education Program.

The K to 12 Basic Education Program adds two years to the past basic education program, suggesting an increased need for teacher supply for the added two year levels, Grades 11 and 12.It has been propounded that the Philippine government may need to offer a better compensation package to attract quality teachers in the field. For Teacher Education Institutions (TEIs), a more aggressive campaign to lure the best students and potential teachers will be essential. The new education program is perceived to transform Philippine education, making it more competitive and responsive to local and regional demands, particularly in consideration of the expected full implementation of the ASEAN Economic Integration by 2015.

The current study may have just provided a tip of the iceberg on the teacher loss phenomenon in the Philippines. Nevertheless, it presents a more realistic scenario on why graduates of teacher education have chosen to shift their life trajectories away from the noble teaching profession.

\subsection{Review of Related Literature}

A commissioned study conducted by Oxford University (2003) explored the prevalence of "teacher loss" among the Commonwealth Caribbean member countries. This report conceptualized four broad dimensions of this phenomenon. First, it can be due to the teacher recruitment by industrialized nations. Second, it can be attributed to teacher recruitment by developing countries. The third dimension is on the career change associated with teacher dissatisfaction with the working conditions. The last dimension is teacher attrition or the inevitable loss of teachers due to retirement or death.

In Australia, the Victorian teacher labor market as revealed by Cameron in 2001 as cited in www.mceecdya.edu.au, emphasized the following factors that may affect the supply of qualified teachers:

$>\quad$ Monetary and non-monetary rewards of the teaching profession;

$>$ Limitation on the number of teacher education courses offered by universities;

$>\quad$ Rate of the net migration of teachers; and

$>\quad$ Relative working conditions. 
A narrative analysis of conversations with graduates who did not pursue teaching

The Canadian Teachers Federation in 2000 reported, on the other hand, that the most significant factor impacting on teacher shortages in the next five years in Canada was on having ageing teacher workforce, while Eurydice (2002) cited that in Europe, the unattractiveness of the teaching profession seemed to contribute to the urgency and importance of finding solutions to the "teacher loss" problem.

In the United Kingdom, Smithers and Robinson (2003) investigated the factors affecting teachers' decisions to leave the profession. There were five main factors identified: workload, new challenges, the school situation, salary, and personal circumstances. Among these factors, they concluded that workload and salary were the most and least important factors, respectively, that influenced teachers to leave their teaching jobs.

Analysis of the career paths of teacher education graduates of the Evergreen State College in the Washington State in the United States of America from 2001 to 2006 revealed that: first, majority of the graduates of teacher education program had their initial job placement within the Washington State: and second, the retention and mobility rates of the 2001 graduates "are retained in their schools at slightly lower rates, but a smaller portion exit the Washington education system compared to the corresponding beginning teachers statewide" (Elfers \& Plecki, 2008 p. 32). Further, the study claims that the patterns that emerged in the analysis suggested a range of vital information for teacher preparation institutions to consider within the Washington State. As Elfers and Plecki, (2008) emphasized "these data serve as a baseline of information to better understand the characteristics of the beginning teacher workforce, the nature of their initial school assignments, and their specific patterns of retention, attrition and mobility (Elfers \& Plecky, p. 33).”

In the Philippine setting, the Department of Education (DepEd) is the primary employer of teacher education graduates. For several years, there had been claims of teacher shortage in public schools. Nevertheless, in 2013, the Department issued (DepEd) Order No. 22, series of 2013, which set the rules for deploying teachers to optimize student-teacher ratios nationwide not only to address the problem of overcrowding in various parts of the country but also to address the teacher shortage.

Such apparent shortage has been well addressed by the Aquino government, as reported by Flores of The Philippine Star (July 12, 2012). According to this report, the government is close to resolving the problem on teacher shortage in public schools with the hiring of at least 55, 848 teaching personnel in June 2013. The hiring process at the Department has also been streamlined. Through the collaborative efforts among the concerned agencies, the Department of Education, the Civil Service Commission, and the Professional Regulation Commission, the Department of Education was able to reduce the hiring period from eight months to three months in 2013 in time for the school opening. A total of 102,603 new teaching positions have been created since the assumption to duty of President Aquino.

These concerted efforts among the agencies under the executive branch of the Philippine government are a much welcome development to address the teacher loss phenomenon. Nonetheless, the current qualitative research study hereby substantiates the apparent loss among the precious teacher education graduates.

\subsection{Conceptual Framework}

Figure 1 depicts the conceptual framework of the study in which the individual narratives of the respondents who decided to pursue non-teaching occupations after graduation were the primary foci of the study. Their experiences during their college days, their reasons for not teaching and eventualities beyond their control were highlighted and analyzed.

Content analyzed narratives were categorized into general themes with corresponding theme definitions serving as inputs to policy recommendations, more specifically on teacher education institutions' admission and retention policies. 


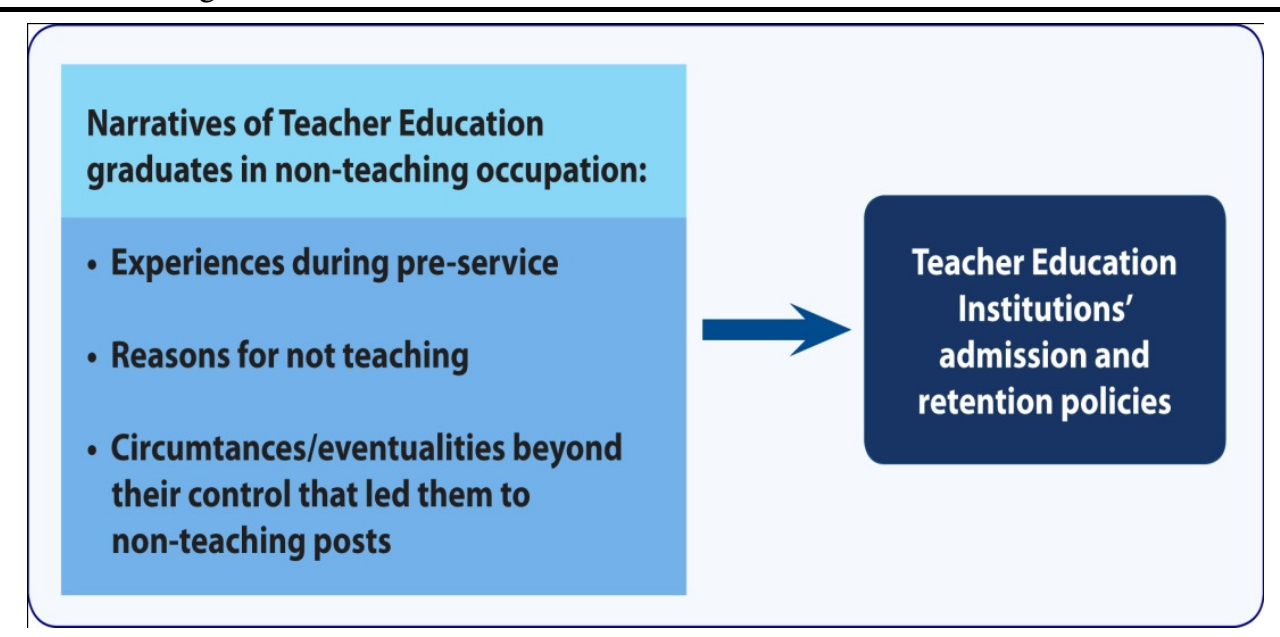

Figure 1. Conceptual Framework

\section{Research Problem}

This study aimed to explore the experiences of teacher education graduates from 10 Teacher Education Institutions in the country from 2007 to 2011, by answering the following research questions:

1. What are the reasons of these graduates who decided not to teach after graduation?

2. What are circumstances or eventualities beyond the graduates' control that led them not to pursue the teaching profession?

3. Given a chance to pursue teaching as their life-long career, what preparations should these graduates embark on?

4. What concrete recommendations can be generated from the results of the study geared towards the refinement or revision of the existing TEIs' policies on admission and retention of students?

\section{Methodology}

This study utilized the in-depth interview method of research. As one of the most common qualitative methods, it is designed to elicit a vivid picture of the participants' perspectives on the research topic. Through this method, the researcher poses questions in a neutral manner, listens attentively to the participants' responses, and asks follow-up questions to probe more deeply based on those responses which arose from the actual conversation as the focus for data analysis.

The following are the guide questions, which facilitated a conversation with each of the respondents, which lasted for an one hour and a half on the average:

1. How would you describe your experiences as a pre-service teacher?

2. What significant events do you consider had inspired you to become a teacher?

3. What made you choose a career other than teaching after graduation?

4. How are you adjusting to a non-teaching occupation?

5. Do you still consider teaching as a career? 
A narrative analysis of conversations with graduates who did not pursue teaching

The participants of the study were 74 teacher education graduates from 2007 to 2011 , from the following normal schools in the Philippines:

\begin{tabular}{cc} 
Region & Participating Normal Schools \\
\hline National Capital Region & Philippine Normal University Main Campus \\
\hline Region I & Mariano Marcos University \\
\hline Region I & Pangasinan State University \\
\hline Region IV-B & Palawan State University \\
\hline Region V & Bicol University \\
\hline Region VII & Cebu Normal University \\
\hline Region IX & Western Mindanao State University \\
\hline Region X & Bukidnon State University \\
\hline
\end{tabular}

Figure 2. List of normal schools

Ten respondents from each of these State Universities were sampled via purposive sampling. The respondents did not ever pursue teaching after graduation, which is the primary criterion for the selection. All conversations were audio recorded and transcribed verbatim. Each transcript of the conversations became the narrative of each of the respondents.

Content analysis was employed to elicit the common themes across the 74 narratives with consideration of the research questions posed in the study. Themes were culled, and frequencies of typical or general perceptions and feelings were determined. The analysis involved the use of Qualyzer Qualitative Data Analysis Software, a content-analysis program that categorized the responses with regard to frequency and salience. The researcher developed the categories of responses based on the grouped responses and the thematic analyses. Fragments of texts in a transcript were selected and associated with a code. Multiple codes were attached to the fragments. Lastly, code hierarchies were developed out of the multiple codes and text fragments.

Interrater validity was undertaken with the research team as the experts. The themes generated were individually analyzed and a group discussion followed examining the definitions as well as the chosen quotes to exemplify the themes that were culled from the interview transcripts. Documentary analysis of the current admission and retention policies of various teacher education institutions was undertaken so as to discern the implication of the themes generated from the narratives of the respondents about these policies.

\section{Results}

\subsection{Motivation for choosing a non-teaching career}

Table 1 presents the themes with the corresponding frequencies of occurrence culled from their motivation for not teaching after graduation in the narratives of the 74 teacher education graduate-respondents. Reasons for not pursuing teaching revolved around concerns pertaining to the graduates' experiences, perceptions of other professions, changes in their interests, comparison of what has been achieved by other graduates, perceived lack of preparation to teach, medical considerations, negative self-evaluation and experiences, physical and environmental considerations, concerns regarding inadequate support for the family, being uncertain about teaching, and perceived mismatch of personality characteristics with teaching.

Aversive Experiences and Negative Teaching Experiences - The graduates pinpointed the negative experiences they encountered before and during their pre-service training. Some of the graduates mentioned that they consider the process of teaching traumatic and tiresome.

"Yes. Traumatic kasi yung process of teaching. Nakakapagod talaga kasi I was assigned in a public school that time. That was a negative experience." (F, 23) 
"Yes. I was traumatized having experienced the process of teaching. It was too tiring as I was assigned in the public school at that time"

Others, on the other hand, saw their friends' experiences as reasons for not pursuing a teaching career. One interviewee shared that his friend got into a difficult situation in the school he was employed in which forced his friend to resign. Another shared that she was not happy about the treatment of her supervising instructor who showed favoritism among the student-teachers she handled. Personal accounts as well as the experiences of their significant others, contributed to their decision not to pursue teaching and chose another job that is not related to teaching. Cross-case analyses of responses indicated that the negative attitudes and behaviors towards the students by their teachers or potential employers had influenced the graduates - that despite their degree, they would rather not teach.

Better Appraisal in Other Professions, Physical and Environmental Considerations, Comparison of Credentials with Others, and Providing Support for the Family - One of the salient responses the graduates pointed out is concerned with comparing various professions in relation to teaching. They perceived that other jobs offer higher compensations and better work conditions (i.e. being in an air-conditioned room). Concerns regarding work safety (being exposed to chalk dust) as well as the demands of longer work hours were emphasized as reasons for not choosing to teach. Some of the respondents also mentioned that they chose jobs nearer to their houses since schools are relatively farther from their place. When it comes to other concerns, prestige seemed to be another concern when it came to work preference.

"That is why I enrolled for a master's degree to prepare me. There is also the financial reason.

And also working as HR seemed to be prestigious at that time. But now I changed my mind and believe that teaching is more prestigious and this is really what I want to do.” (F, 22)

Others saw other professions as having more control and power. One respondent pinpointed that being a police cop is better when it comes to being effective in providing security and protection which are also required of teachers. On comparing credentials with others, the graduates saw that their abilities were not parallel with other students in the same program. A respondent commented that during the selection process in schools, he realized that his credentials may not be considered because of the people he may be pitted against with:

"Pini-prepare ko pa yung sarili ko kasi pag dating mo sa school ano ka eh marami kang makakasama na co-teachers mo na magagaling, professors na matatalino, na sa tingin ko that time, wala akong credentials or wala pa akong potential na puwedeng maka-level sa kanila.” (M, 24)

"I was preparing myself because I know that when I apply in schools, I will be with the company of co-teachers, professors who are good, effective, and intelligent. That time I felt that I cannot level up to their capabilities"

Lastly, one of the motivations that the graduates mentioned was in terms of what can be provided for their families as a result of their employment. This did not only cover financial concerns but also issues pertaining to: working nearer their house so that they can still look after their parents; wanting to have a more stable family by means of being able to provide for their needs; thinking that lower salaries are offered to teachers that time; and being given the role of taking care of the family.

Medical Considerations, Negative Self-Evaluation, Uncertainty about Teaching and Personal Characteristics Mismatch - Internal issues concerning health, perceptions, and apprehensions were salient in the responses of the graduates. Some reported that they had issues pertaining to certain medical conditions that required them to take a job that would not force them to physically exhaust themselves

"When I entered college I wasn't really sure what I would want myself to become. Secondly, when I started teaching I noticed that my throat tended to bleed. I consulted an EENT, and the 
A narrative analysis of conversations with graduates who did not pursue teaching

doctor advised me that I should not strain my voice too much and that I should look for a job

that does not require me to talk too much.” (M, 22)

Other graduates expressed negative beliefs about themselves and assumed that they will not pass the licensure examination. The idea of taking the examination and not passing it made them decide not to pursue teaching and to find a job that would not require a license. However, the respondents also admitted that they would want to try to take the examination because they had found joy in teaching during their practicum in college. There were respondents, on the other hand, who were not sure of what they really wanted, that is why they chose teaching as an option before pursuing the course that they might eventually want to take. However, these respondents ended up finishing the course and still not being sure about what they want. This led them to pursue other jobs that are not related to the teaching profession. Lastly, most of the respondents regarded themselves not fitted to teach as they believed they do not have the personality characteristics required of teachers. The differences in personality characteristics were brought out in relation to how younger people behave nowadays, and the graduates perceived that they would not be able to handle the younger generation.

\section{Table 1}

Generated Themes and Theme Definitions on the Reasons for Not Teaching

\begin{tabular}{|c|c|c|}
\hline Generated themes & Theme definition & Frequency $*$ \\
\hline Aversive experience & $\begin{array}{l}\text { This describes the negative experiences during the pre-service } \\
\text { training. }\end{array}$ & 12 \\
\hline $\begin{array}{l}\text { Better appraisal in other } \\
\text { professions }\end{array}$ & $\begin{array}{l}\text { This refers to comparisons of professions that lead the graduates to } \\
\text { realize that professions other than teaching have better stature in } \\
\text { terms of salary and working conditions. }\end{array}$ & 40 \\
\hline Change in preference & $\begin{array}{l}\text { This indicates changes in one's interest, like seeing other course } \\
\text { mates who became successful even if they did not go into teaching } \\
\text { or being comfortable in the jobs they first got into after college } \\
\text { before taking the LET. }\end{array}$ & 18 \\
\hline $\begin{array}{l}\text { Comparison of } \\
\text { credentials with others }\end{array}$ & $\begin{array}{l}\text { This indicates the extent of insecurities with one's capabilities to } \\
\text { teach, credentials and potentials as compared with others. }\end{array}$ & 14 \\
\hline $\begin{array}{l}\text { General preparation for } \\
\text { teaching }\end{array}$ & $\begin{array}{l}\text { This refers to how they were able to mentally prepare themselves } \\
\text { for teaching after graduation as well as possessing the needed skills. }\end{array}$ & 14 \\
\hline Medical considerations & $\begin{array}{l}\text { This describes the choice a person takes after considering different } \\
\text { jobs because of medical conditions that may affect him/her if } \\
\text { he/she pursues teaching. }\end{array}$ & 22 \\
\hline Negative self-evaluation & This focuses on negative beliefs about one's ability and potentials. & 18 \\
\hline $\begin{array}{l}\text { Negative teaching } \\
\text { experiences }\end{array}$ & $\begin{array}{l}\text { This describes personal accounts and the experiences of others in } \\
\text { the teaching profession. }\end{array}$ & 11 \\
\hline $\begin{array}{l}\text { Physical and } \\
\text { environmental } \\
\text { considerations }\end{array}$ & This includes work, work place safety, and other related concerns. & 11 \\
\hline $\begin{array}{l}\text { Providing support for } \\
\text { immediate family }\end{array}$ & $\begin{array}{l}\text { This concerns the motivation to provide the family with a } \\
\text { comfortable living arrangement by earning a higher salary that } \\
\text { teaching may not provide. }\end{array}$ & 37 \\
\hline $\begin{array}{l}\text { Uncertainty about } \\
\text { teaching }\end{array}$ & $\begin{array}{l}\text { This describes feelings of uncertainty about teaching where the } \\
\text { graduate have little to no knowledge of the opportunities one has in } \\
\text { pursuing teaching as a course. }\end{array}$ & 17 \\
\hline $\begin{array}{l}\text { Mismatched personal } \\
\text { characteristics with } \\
\text { teaching }\end{array}$ & $\begin{array}{l}\text { The graduates perceive that their personal characteristics are not } \\
\text { what are required of the teaching profession }\end{array}$ & 30 \\
\hline
\end{tabular}

Note. *Multiple Responses

\subsection{Circumstances and eventualities that lead the respondents to non-teaching occupations}

Circumstances and eventualities in the lives of the graduate-respondents were likewise documented in examining what were the precursors in not pursuing teaching. Events that affected their decisions concentrated on comparisons regarding compensation, aversive and negative experiences brought about by being exposed and 
Abulon, E. L. R., \& Rungduin, T. T.

their vicarious experiences, medical reasons, physical and environmental conditions.

On a macro level, as can be gleaned from Table 2, the graduates saw that other professions were more profitable at the time of their graduation with considerations pertaining to the need to take the licensure examinations and their experiences during their practice teaching. Some of the graduates saw that it was imperative to help their families first by taking any work that would first become readily available after graduation. The choices for working outside of teaching also had to do with accessibility and workload as well as seeing other course mates becomes successful in fields other than teaching.

Medical concerns came out as a salient theme in relation to choosing another field. The respondents felt that teaching was more stressful as opposed to office work, while others were advised by health professionals to inhibit their activities related to talking and long hours of standing, which are part of the teacher's duties inside the classroom.

\section{Table 2}

Generated Themes and Theme Definitions on the Events and Circumstances for not Teaching

\begin{tabular}{|c|c|c|}
\hline Generated themes & Theme definition & Frequency* \\
\hline $\begin{array}{l}\text { Aversive } \\
\text { experience }\end{array}$ & $\begin{array}{l}\text { This describes the negative experiences during their pre-service } \\
\text { training. }\end{array}$ & 12 \\
\hline $\begin{array}{l}\text { Better appraisal in } \\
\text { other professions }\end{array}$ & $\begin{array}{l}\text { This refers to comparisons of professions that lead the graduates to } \\
\text { realize that professions other than teaching have better stature in terms } \\
\text { of salary and working conditions. }\end{array}$ & 39 \\
\hline $\begin{array}{l}\text { Change in } \\
\text { preference }\end{array}$ & $\begin{array}{l}\text { This indicates changes in one's interest after seeing other course mates } \\
\text { who became successful even if they did not go into teaching or being } \\
\text { comfortable in the jobs they first got after college before taking the } \\
\text { LET. }\end{array}$ & 18 \\
\hline $\begin{array}{l}\text { Medical } \\
\text { considerations }\end{array}$ & $\begin{array}{l}\text { This describes the choice a person takes in considering different jobs } \\
\text { because of medical conditions that may affect them if they pursue } \\
\text { teaching. }\end{array}$ & 20 \\
\hline $\begin{array}{l}\text { Negative teaching } \\
\text { experiences }\end{array}$ & $\begin{array}{l}\text { This describes personal accounts and the experiences of others in the } \\
\text { teaching profession. }\end{array}$ & 10 \\
\hline $\begin{array}{l}\text { Physical and } \\
\text { environmental } \\
\text { considerations }\end{array}$ & This includes work, work place safety, and other related concerns. & 10 \\
\hline $\begin{array}{l}\text { Providing support } \\
\text { for immediate } \\
\text { family }\end{array}$ & $\begin{array}{l}\text { This concerns the motivation to provide the family with a comfortable } \\
\text { living arrangement by earning a higher salary that teaching may not } \\
\text { provide. }\end{array}$ & 34 \\
\hline
\end{tabular}

Adjustments of the Graduates - When asked about adjustments brought about by the circumstances and events that triggered their decision not to teach, the graduates mentioned that there were adjustments with regard to acquiring and adjusting to the new skills, improved ability to interact with others, social facilitation, and transfer of learning.

Acquiring and adjusting to new and needed skills - Learning new skills for a new job became a challenge when the respondents took on a job other than teaching. The idea of adjusting for the sake of getting a new job proved to be tedious as the respondents had to become adept with skills required, such as handling financial concerns or recruitment responsibilities. However, there were respondents who reported that the new skills were relatively easy because of their acknowledgment of the idea that learning is a continuous process.

\footnotetext{
"It doesn't really require you to be a business/finance graduate to get in but it's a plus. Learning is a continuous process. I was able to learn how to be a teacher, and now I am continuously learning about the banking industry." (M, 24)
}

The tendency to alter skills learned is another factor in adjusting to a new job. Since the job they intended to 
A narrative analysis of conversations with graduates who did not pursue teaching

pursue did not really require an alteration of prior skills, efforts in doing so made them prefer to keep their prior skills.

"Because my work is more on figures, more on numbers. So sa teaching is more on principles, theories, and then how to deal with children. Hindi yan naituro sa education, lalong-lalo na yung sa accounting. So mahirap, so mga ilang buwan din ako nag-adjust.”(F, 26)

"Because my work is more on figures, more on numbers. Teaching is more focused on principles, theories, and how to deal with children. It was not taught in education especially those concerning accounting. It was difficult and it took me months to adjust.” (F, 26)

Improving the Ability to Interact with Others and Improving One's Personal Characteristics - An area that the respondents perceived to have changed and had adjusted to when they had chosen another job was in the area of communicating with others. The respondents admitted that they had better communication skills when they started working, and they were able to meet different people who contributed to their knowledge and skills

"Ah siyempre every day I am dealing with different people. Management, staff, then suppliers, so through this [these] different characters, I can easily adjust to them yung strategy ko dito dealing to each person ay iba-iba. So I need to adjust to them." (M, 25)

"Every day I deal with different people, from the management, to the staff to suppliers. This is why I need to strategize and effectively deal with them.” (M, 25)

Table 3

Generated Themes and Theme Definitions on Adjustments Made in Non-Teaching Jobs

\begin{tabular}{|c|c|c|}
\hline Generated themes & Theme definition & Frequency* \\
\hline $\begin{array}{l}\text { Acquiring new and } \\
\text { needed skills }\end{array}$ & The learning of new skills needed in the performance of a new job & 15 \\
\hline $\begin{array}{l}\text { Adjusting to } \\
\text { acquired skills }\end{array}$ & $\begin{array}{l}\text { The tendency to alter skills learned because these skills are not needed } \\
\text { or demanded in their new jobs }\end{array}$ & 13 \\
\hline $\begin{array}{l}\text { Improving the } \\
\text { ability to interact } \\
\text { with others }\end{array}$ & The need to effectively communicate with different types of people & 15 \\
\hline $\begin{array}{l}\text { Improving personal } \\
\text { characteristics }\end{array}$ & $\begin{array}{l}\text { The development of personal characteristics, such as the need to refine } \\
\text { one's attitude, disposition, and emotional aspect of the person. }\end{array}$ & 26 \\
\hline Social facilitation & $\begin{array}{l}\text { The adjustment was considered easy due to the support provided by } \\
\text { significant individuals - both in their personal and professional needs. }\end{array}$ & 11 \\
\hline $\begin{array}{l}\text { Transfer of } \\
\text { previous learning to } \\
\text { current profession }\end{array}$ & $\begin{array}{l}\text { The strategy or the belief that acquired skills in teaching can be used in } \\
\text { other professions dealing with people. }\end{array}$ & 14 \\
\hline
\end{tabular}

\subsection{Preparations done if given a chance to go back into teaching}

The respondents were further asked regarding pursuing teaching as a career and whether they see the need to prepare for it. Table 4 shows that the majority of the respondents expressed that when they have the opportunity, they will actually pursue teaching. The generated themes revolved around their feelings about teachings, cognitions about their educational experiences and pre-service training, and their actual preparations to go back to teaching.

Acquisition of necessary skills for teaching and Career Goal Clarification - The respondents were clear when they expressed that they still wanted to acquire more skills that they felt are necessary for teaching. Some of the respondents felt that they needed to be trained further and felt that their training was not enough for them to actually teach. The interviewees also expressed that they wanted to teach and that they felt that teaching is one 
Abulon, E. L. R., \& Rungduin, T. T.

of their career goals. The respondents expressed that they need to be financially stable to enroll in a master's program and eventually teach.

"Sa akin ay after graduation I would say to myself that I really want to teach. I want to pass my licensure examination, but sad to say, I was not able to take my board examination.” (F, 28)

"After graduation, I said to myself that I would teach and pass the licensure examination.

Unfortunately, I was not able to take the examination." (F, 28)

General Positive Appraisal and Positive Relationships - The respondents expressed their desire to go back into teaching because of their general positive appraisal of education and their teachers. Though there were negative experiences shared, in general, the graduates saw that teaching is a respected profession and teachers are to be treated as role models and with high regard. They also mentioned teachers who had positive impact on their lives as well as positive experiences with their classmates and fond memories of their institutions.

"My teachers in elementary and high school inspired me to be a teacher, but more than that, I

believe that teaching is a good profession with a lot of opportunities.” (F, 22)

Negative Evaluation of specific experiences - Pre-service training was evaluated negatively due to perceived difficulties encountered in the course of finishing the degree. This negative evaluation became the basis in evaluating the training as negative. There were graduates who related experiences about the training, classmates and teachers they perceived as negative and were used as precursors to not choosing teaching as a career.

Self-development and improvement and Widening Opportunities - Most salient in the responses of the respondents is the experience of specific changes within them as an effect of their college experiences. They felt a sense of development as they finished the course. Moreover, widened opportunities were also college experiences that allowed them to explore different opportunities (e.g. earning money while studying, traveling to different places and performing various roles in school). It allowed them to think of greater opportunities to take as they graduate from school.

\section{Table 4}

Generated Themes and Theme Definitions of the College Experiences of the Respondents

\begin{tabular}{|c|c|c|}
\hline Generated themes & Theme definition & Frequency* \\
\hline $\begin{array}{l}\text { Acquisition of } \\
\text { necessary skills for } \\
\text { teaching }\end{array}$ & $\begin{array}{l}\text { This describes specific and global skills that were acquired in the course } \\
\text { of their education. They were able to link these skills with the needed } \\
\text { competencies for teaching. }\end{array}$ & 30 \\
\hline $\begin{array}{l}\text { Career goal } \\
\text { clarification }\end{array}$ & Their experiences in pre-service teaching clarified their career goals. & 14 \\
\hline $\begin{array}{l}\text { General positive } \\
\text { appraisal }\end{array}$ & The respondents' general evaluation of their pre-service training & 10 \\
\hline $\begin{array}{l}\text { Negative evaluation } \\
\text { of specific } \\
\text { experiences }\end{array}$ & $\begin{array}{l}\text { Pre-service training is evaluated negatively due to perceived difficulties } \\
\text { encountered in the course of finishing the degree. This negative } \\
\text { evaluation became the basis in evaluating the training as negative. }\end{array}$ & 22 \\
\hline $\begin{array}{l}\text { Positive } \\
\text { relationship }\end{array}$ & $\begin{array}{l}\text { This describes how positively the graduates saw their relationships with } \\
\text { the school, administrations, their teachers, classmates, and friends. }\end{array}$ & 24 \\
\hline $\begin{array}{l}\text { Self-development } \\
\text { and improvement }\end{array}$ & $\begin{array}{l}\text { This is described as the specific changes within the graduates as an } \\
\text { effect of their college experiences. }\end{array}$ & 41 \\
\hline Self-evaluation & $\begin{array}{l}\text { This pertains to how one would assess his or her performance while } \\
\text { pursuing the degree. }\end{array}$ & 12 \\
\hline $\begin{array}{l}\text { Widening } \\
\text { opportunities }\end{array}$ & $\begin{array}{l}\text { This refers to the college experiences that allowed them to explore } \\
\text { different opportunities (e.g. earning money while studying, traveling to } \\
\text { different places and performing various roles in school). }\end{array}$ & 9 \\
\hline
\end{tabular}


Interestingly, the respondents pointed out that the influence of their family members who were also in the field of teaching motivated them to go back into teaching. Seeing their relatives do well in teaching provide them with hope that if they go back into teaching, they would actually succeed. Most of the respondents referred to their earlier cognitions of teaching where they had positive experiences with their teachers and being in school. Most admitted that they had really wanted to teach; however, due to the waiting time for the licensure examination and other financial concerns, they chose another profession.

The respondents also saw that being a teacher is a profession that is treated with reverence. This is why, for most of the respondents, going back to teaching as one of their highest priorities. They perceived that becoming a teacher remains a career choice because of its viability and vitality. Lastly, the respondents admitted that although they did not see teaching as their priority course, they had come to like it and given the opportunity they would teach in the future. Table 5 presents the themes which embody what motivated the graduate-respondents to become teachers.

\section{Table 5}

Generated Themes and Theme Definitions on the Graduates' Motivation for Choosing Teaching as a Career

\begin{tabular}{llc}
\hline \multicolumn{1}{c}{ Generated themes } & \multicolumn{1}{c}{ Theme definition } & Frequency* \\
\hline Correspondence & $\begin{array}{l}\text { This refers to diverging one's interest with what is required } \\
\text { in teaching. }\end{array}$ & 15 \\
\hline $\begin{array}{l}\text { Early life conceptions of } \\
\text { teaching }\end{array}$ & $\begin{array}{l}\text { This describes how the graduates perceived being a teacher } \\
\text { based on their life experiences. }\end{array}$ & 13 \\
\hline External attribution & $\begin{array}{l}\text { This pertains to the perception that there are external } \\
\text { precursors that necessitate one to teach (e.g. calling) }\end{array}$ & 11 \\
\hline $\begin{array}{l}\text { Influences of family } \\
\text { members }\end{array}$ & $\begin{array}{l}\text { This refers to members of the family who are teaching or } \\
\text { relatives who are encouraging the graduates to teach. }\end{array}$ & 17 \\
\hline Goal & $\begin{array}{l}\text { This focuses on the desire of the graduate to pursue } \\
\text { teaching. }\end{array}$ & 15 \\
\hline Life span of career choice & $\begin{array}{l}\text { This pertains to the longevity of a career choice. For the } \\
\text { graduates, teaching is a lifelong profession. }\end{array}$ & 16 \\
\hline $\begin{array}{l}\text { Positive cognition about } \\
\text { teaching }\end{array}$ & $\begin{array}{l}\text { This refers to positive beliefs, thoughts, and attitudes } \\
\text { towards education, especially of what it brings out in people. }\end{array}$ & 16 \\
\hline Previous school experiences & $\begin{array}{l}\text { This refers to the experiences the graduates had from } \\
\text { elementary up to tertiary with their classmates, teachers, and } \\
\text { the school that inspired them to become teachers. }\end{array}$ & 17 \\
\hline $\begin{array}{l}\text { Random choice leading to a } \\
\text { realization }\end{array}$ & $\begin{array}{l}\text { This describes not being motivated to teach at first but } \\
\text { eventually realizing the positive aspects of teaching. }\end{array}$ & 10 \\
\hline $\begin{array}{l}\text { Vicarious experiences } \\
\text { reinforcing teaching as a } \\
\text { career }\end{array}$ & $\begin{array}{l}\text { These are events lifted from the experiences of others that } \\
\text { lead the graduates to go back to teaching. }\end{array}$ & \\
\hline
\end{tabular}

Note. *Multiple Responses

The respondents were then asked about their preparations to be able to go back to teaching. As presented in Table 6, most of them expressed their plan to pursue an advanced training in education by enrolling in professional development programs such as certifications and graduate degrees. They also pinpointed personal and professional improvements that they were undertaking in preparation for teaching, which include improving one's personal characteristics (i.e. patience, generosity, commitment), improving communication skills (i.e. enrolling in a language proficiency course), and improving one's vocational skills (i.e. enrolling in TESDA programs). 
Abulon, E. L. R., \& Rungduin, T. T.

Table 6

Generated Themes of the Preparations They Are Undertaking to Be Able to Go Back to Teaching

\begin{tabular}{llc}
\hline \multicolumn{1}{c}{ Generated themes } & & \multicolumn{1}{c}{ Theme definition } \\
\hline $\begin{array}{l}\text { Advance training in } \\
\text { education }\end{array}$ & $\begin{array}{l}\text { This refers to the intention to pursue or obtain further training in } \\
\text { education or teaching in order to prepare them for the profession. }\end{array}$ & 16 \\
\hline $\begin{array}{l}\text { Personal and } \\
\text { professional } \\
\text { improvements }\end{array}$ & $\begin{array}{l}\text { These are the areas the respondents emphasized in becoming more } \\
\text { prepared in pursuing a career in teaching. }\end{array}$ & 21 \\
\hline $\begin{array}{l}\text { Being part of allied } \\
\text { professions in } \\
\text { teaching }\end{array}$ & $\begin{array}{l}\text { This refers to going back to teaching but not directly in terms of } \\
\text { teaching loads; instead in terms of providing assistance in the general } \\
\text { delivery of instructions (i.e. guidance and library work). }\end{array}$ & 15 \\
\hline Note. *Multiple Responses & &
\end{tabular}

\section{Discussion}

Available literature indicate that programs intended to attract new teachers and keep old ones in service via salary upgrades had been considered in a number of countries. Sclafani (2011) reported that Australia, Denmark, England, Finland, Norway, and Scotland raised starting salaries to encourage teachers to enter the field. Austria, Japan, and Portugal concentrated in retaining mid-career teachers, while Greece, Hungary, and New Zealand offered salary increases to experienced teachers.

In some OECD countries, including the United States, incentives such as loan condonation and signing bonuses had also been considered aside from raising salaries. The report, however, clarified that there is little research evidence to demonstrate that these incentive strategies work (Sclafani, 2011). Sclafani (2011) also cited various pre-service and start-of-service programs to attract teacher education graduates into the teaching profession. These programs can be considered in the Philippines. A rundown of these programs are as follows:

$>\quad$ Scholarships in exchange for a definite service requirement (Australia);

$>$ Grant of special allowances, stipends, computers, and free accommodation or housing to potential teachers in remote areas (Denmark, United Kingdom, and United States);

$>\quad$ Special job placements in priority schools (France); and

$>\quad$ Alternative Certification Programs or ACP to recruit people with better academic preparation and also to encourage mid-career professionals to move into teaching (US).

Sclafani (2011) also reported that some countries experience high attrition rate of teachers during the first five years of service. The attrition rate can reach as high as $50 \%$ in some countries, including the US. To address this, induction programs were offered to ensure smooth transition for new teachers in their initial years in service. Additional training and mentoring by experienced teachers were given new teachers. Among the countries that have considered induction programs include England, Wales, France, Greece, Israel, Italy, Japan, Korea, Northern Ireland, Australia and Switzerland. Hong Kong also recently paid close attention to induction of new teachers (Asia Society, 2011).

In Korea, new teachers are given a two-week pre-employment training program on classroom management, student counseling, and teacher tasks with methods involving the use of case studies and practical tasks. For the first six months of teaching, new recruits were given "instructional guidance and evaluation, classroom supervision and life guidance, student specialty and aptitude guidance, and supervision of clerical work" (Sclafani, 2011 p. 4). Switzerland offered a longer two-year induction program, a required component of certification. Three levels of support were provided: mentor/mentee learning; courses for new teachers through the teacher education program, either required or voluntary; and voluntary consultations with new teachers by the Department of Education in the area (Sclafani, 2011). 
A narrative analysis of conversations with graduates who did not pursue teaching

On another aspect, Sclafani (2011) shared that Korea also considered setting a limit to entrants to elementary education. No limit to entrants to secondary education had been set, although only about $20 \%$ eventually found employment. It was believed that limiting access to teacher education programs can raise the prospects of employment for successful graduates. Proceedings from the International Summit on Teaching Profession in 2011 also noted the importance of boosting the public image of teachers and creating a professional working environment for them. This approach can be just as important as salary upgrading, according to the Summit report. Key specific strategies include campaigns in mass media to promote or protect the public image of teachers, institutionalization of a public recognition day for teachers, improving and simplifying school management, stronger teacher engagement in important school decisions, tapping of pre-service teachers in improving lesson quality, strengthening the aspect of ethics in teacher preparation programs, addressing gender imbalance in the profession, making available of online professional development programs, and providing school leadership trainings (Asia Society, 2011).

These global trends geared towards downsizing the teacher loss phenomenon provided the current study with a well spring of policy pointers and recommendations. In the Philippine setting, it is imperative to explore the implications of the findings with the admissions policies of teacher education institutions for incoming teacher education students. Reforms in scholarship programs and civil service eligibility may also be explored as supplemental incentives to minimize wastage of teacher preparation. Perusal of the admissions policies as posted in the websites of the universities nationwide, the following policies were noted in relation with the findings of the study:

\subsection{On admissions policies}

Teacher Education Institutions (TEIs) may consider the waiver of entrance/admission examinations, certain documentary requirements (e.g., original NSO birth certificates), and even the payment of application/testing fees to ease entry for prospective teacher education students. These incentives need not be implemented across-the-board and may only be focused on the following entrants to teacher education:

$>\quad$ those graduating from high school with honors;

$>\quad$ those meeting a certain minimum GPA (e.g., 90\%); and

$>$ those coming from low-income families as certified by the Department of Social Welfare and Development (DSWD).

At the University of Santo Tomas (UST), the application fee for high school students who are candidates to graduate and belong to the top 5 of their batch is waived. On the other hand, Siliman University observes an Open Admission policy by lifting the requirement on admission and placement examination. The Central Philippine University only requires Form 138 and NSO birth certificate (original and photocopy) for incoming freshmen, while the University of Cordilleras only require Form 138, birth certificate, and Certificate of Good Moral Character (CGMC).

\subsection{On scholarships for freshmen including teacher education students}

An institutionalization of scholarship programs for deserving teacher education students may also help encourage more young people to go into teacher education. The entrance scholarship programs of Mariano Marcos State University (MMSU) may be worth emulating by other SUCs and TEIs. MMSU awards entrance scholarship to those who graduated as valedictorian, salutatorian, first, second or third honorable mention of a class of 50 or more students for the first semester in the university. The valedictorian enjoys free tuition fee and a stipend of 1,500 pesos. The salutatorian enjoys free tuition fee and a stipend of 1,000 pesos. The first, second and third honorable mention enjoy free tuition fee. 


\subsection{On policy for transferees}

There might also be a need to review the existing policies and requirements of SUCs and TEIs on transferees, for streamlining and standardization across these institutions. Perhaps the transfer of teacher education students with potential and valid reason/s for transfer needs to be facilitated, instead of discouraged. West Mindanao State University, for instance, has a long list of requirements for transferees, which include certificate of eligibility to transfer, original and photocopy of college entrance exam results, medical certificate, and college admission evaluation form. The University of Cordilleras, on the other hand, only requires certificate of honorable dismissal, true copy of scholastic records, and certificate of good moral character.

The thematic analysis of the qualitative data gathered in the study identified the following as the major reasons that prevented teacher education graduates from pursuing teaching jobs:

$>\quad$ Better appraisal of other professions;

$>\quad$ Better opportunities to persuade support for immediate family while in other professions;

$>\quad$ Mismatched personal characteristics with teaching; and

$>$ Medical/health reasons.

The graduate-respondents' perception of the heavy workload of the teaching profession may have triggered them to shift to jobs they appraised as rather easier and more time-bound. This particular result mirrors what have caused the "teacher loss phenomenon" in some countries like in the United States, Australia, and United Kingdom as cited in the review section (see Oxford University, 2003; Cameron, 2001; Smithers \& Robinson, 2003). Based on the results of these studies, teacher workload was identified as the common denominator when teachers were asked why they leave their teaching profession.

Moreover, better appraisal of other professions could have stemmed from the graduates' negative evaluation of their pre-service training due to perceived difficulties encountered in the course of finishing the degree (e.g. difficulties encountered during the off-campus course). It is also worthy to note the confessions made by around 22 out of the 74 graduate-respondents regarding health conditions that may affect them if they pursue teaching; thus, prompting them to consider other jobs. Such decision may have resulted from their observation about the workload as well as the working conditions of the teachers are having in the field during their practice teaching course.

Among the graduates of teacher education interviewed in the study, it is significant to note how the Filipino cultural values have influenced their career choices. Most of the graduates grabbed other job opportunities that had come along right after graduation to make sure that they would be able to immediately provide financial assistance to their family. Such phenomenon cannot be overstated considering the economic situation in the country. Hence, some implications as to financial rewards in the teaching profession as well as in the hiring process of teachers can be deduced in this respect.

\section{Conclusions}

The rich narrative data gathered in the study showed that financial and economic reasons, which include perceptions of insufficient salary levels, are driving the graduates away from the teaching career. Likewise, a mismatch between personal characteristics, including health issues related to the demands of teaching profession, were crystallized through the qualitative analysis.

Although a number of the respondents admitted that they do not see themselves as teachers even if it was their training, yet, they expressed seeing themselves as part of professions allied to teaching. These graduates applied for jobs that are related to teaching such as becoming guidance counselors, librarians, teacher assistants, 
A narrative analysis of conversations with graduates who did not pursue teaching

and other professions related to caring for children. The respondents care about children but do not see themselves as teachers; hence they opted instead to choose careers which would give them opportunities to be in constant exposure to children

A myriad of possible reforms and initiatives can be considered to address these concerns. In the pre-service phase, reforms starting with the recruitment and selection of students, provision of scholarships for deserving students, institutionalization of career-oriented programs to sustain motivation to pursue teaching, and curricular reviews of some aspects of the practice teaching course as well as of basic teacher competencies. In the in-service phase, reforms in the hiring process, provision of in-service enticements for beginning teachers, and, most of all, review of the starting salary of teachers are deemed necessary and timely.

\subsection{Recommendations}

The following policy recommendations for consideration of teacher education institutions are offered: It is also worthy to provide the following policy recommendations for consideration of concerned the Philippine government agencies.

\section{References}

Asia Society. (2011). Improving teacher quality around the world. International Summit on Teaching Profession. Retrieved from http://asiasociety.org/files/lwtw-teachersummit report0611.pdf

Cameron, L. (2001). Demand and supply of primary and secondary school teachers in Australia. Retrieved from http://www.mceetya.edu.au/verve/_resources/part_g.pdf

Canadian Teachers' Federation. (2000). Teacher supply and demand survey 2000-2005: Analysis for French districts' in economics services bulletin. Retrieved from http://www.scseec.edu.au/site/

Department of Education. (2013). Revised guidelines on the transfer of teachers from one station to another Retrieved from http://schoolsmanagement.blogspot.com/2013/04/deped-order-22-s-2013-revised.html

Elfers, A., \& Plecki, M. (2008). Analyzing the career paths of teacher education graduates in Washington State: Institution report for the Evergreen State College, University of Washington. Retrieved from http://www.evergreen.edu/mit/docs/Evergreen\%20FINALstudy.pdf

Eurydice. (2002). The teaching profession in Europe: profile, occupational content and key issues: General and methodological framework of the study. Retrieved from http://www.eurydice.org/Documents/KeyTopics/en/FrameSet.html

Flores, H. (2012). DepEd hires 55,848 teachers. The Philippine Star, Retrieved from http://www.abs-cbnnews.com/nation/07/11/13/deped-hires-55848-teachers

Oxford University. (2003). Teaching at risk, teacher mobility and loss in Commonwealth member States Retrieved from http://hivhealthclearinghouse.unesco.org/sites/default/files/resources/teaching\%20at\%20risk.pdf

Sclafani, S. K. (2011). Recruiting, training and supporting a 21st century teaching profession. Retrieved from http://asiasociety.org/files/lwtw-teachered.pdf

Smithers, A., \& Robinson, P. (2003). Factors affecting teachers' decisions to leave the professions. Research Report No. 430. The University of Liverpool. Retrieved from http://webarchive.nationalarchives.gov.uk/20130401151715/ 
Abulon, E. L. R., \& Rungduin, T. T. 